\title{
Expanding the Parameters of Academia
}

\begin{abstract}
This paper draws on qualitative data gathered from two studies funded by the UK Leadership Foundation for Higher Education (Whitchurch 2008; 2009) to examine the expansion of academic identities in higher education. It builds on Whitchurch's earlier work, which focused primarily on professional staff, to suggest that the emergence of broadly based projects such as widening participation, learning support and community partnership is also impacting on academic identities. Thus, academic as well as professional staff are increasingly likely to work in multi-professional teams across a variety of constituencies, as well as with external partners, and the binary distinction between 'academic' and 'non-academic' roles and activities is no longer clear-cut. Moreover, there is evidence from the studies of an intentionality about deviations from mainstream academic career routes among respondents who could have gone either way. Consideration is therefore given to factors that influence individuals to work in more project-oriented areas, as well as to variables that affect ways in which these roles and identities develop. Finally, three models of academically oriented project activity are identified, and the implications of an expansion of academic identities are reviewed.
\end{abstract}

\section{Introduction}

Despite an extensive literature on academic identity (for instance Becher and Trowler 2001; Henkel 2000; Deem, Hillyard and Reed 2007; Kogan and Teichler 2007; Enders and de Weert 2009), and on the incorporation of practice-related disciplines into the academy (for instance Stromquist et al 2007; El-Khawas 2008; Gordon and Whitchurch 2010; Rhoades 2007), the implications of academic activity that takes place outwith mainstream spheres of teaching, research and, in some higher education systems, third leg or service activity, have not been fully explored. This paper begins to fill this space by drawing on the narratives of a sub-set of twenty-five respondents from two studies funded by the UK Leadership Foundation for Higher Education (Whitchurch 2008; 2009), who had roles with significant academic elements such as teaching and tutoring, programme design, or some form of applied research. The majority had doctorates, previous experience of teaching and/or research in adult, further or higher education, and publication records, usually in relation to practicebased research. It was clear that a number of them could have gone either way, into a mainstream academic, or into a more project-oriented type of role, and some had moved in and out of academic roles. Although not generally categorised as 'academic' for employment purposes, some had split 'academic' and 'non-academic' contracts.

The respondents were drawn from institutions in the UK, Australia and the United States, as follows: 
- Five UK institutions: three pre-1992, and two post-1992 universities.

- Two Australian institutions: one research-intensive, sandstone university; and one teaching-oriented, post-merger institution, created from a number of colleges of technical and further education.

- Two public institutions in the United States: one a state university with a balanced teaching and research profile; and the other a world-class, researchintensive university.

The choice of institutions did not seek to reflect the diversity of each national system, but took account of contextual variables such as institutional structure and mission, as well as regional and national agendas. It was also possible to make comparisons between the US system, which is strongly market-oriented but also takes seriously its public service role, and the UK and Australian systems, which are becoming more market-oriented against a background of increasing resource constraints. Public funding in the latter countries is also strongly influenced by the outcomes of teaching and research assessment exercises, and a contribution to the national economy expressed in terms of, for instance, employability and skills agendas. In all three countries, respondents were employed by their institutions rather than by local or national government, as is the case in some European countries. In the US, links with regulatory and funding bodies were likely to be at the level of state legislatures.

Gatekeepers in each institution were asked to nominate respondents who had mixed academic and professional elements in their roles, including, for instance, academic staff who were heading up a spin out or partnership unit; or professional staff who undertook roles such as teaching support in study skills or outreach, or research into issues such as student choice or retention rates. The backgrounds of respondents included:

- Adult, further or higher education

- Lifelong learning/continuing education

- School teaching and teacher education

- English as a second language

- Academic literacy/study skills

- Policy research into eg regional and overseas development

- Scientific research and practice.

They were involved in five main fields of activity having academic components, as follows:

[position Table 1 here]

Respondents were also likely to combine disciplinary interests with project portfolios and/or research into policy and practice. As illustrated in Figure 1, activity related to project portfolios could co-exist with, be informed by, and feed into mainstream academic and institutional activity, as well as creating feedback loops with wider networks:

[position Figure 1 here]

Involvement in projects with academic components would be likely to suit what Dowd and Kaplan (2005) refer to as "boundaryless" academic staff who take a 
freewheeling approach to career development. Some people would be likely to move in and out of project space, seeing it as a place in which intellectual or career refreshment might occur, perhaps aligned with study leave. There was also some evidence from the studies that people in this space may be either at the beginning or the end of their careers, the former using it as exploratory space or a stepping stone to an academic or other type of career; the latter pursuing a specific interest that they had not been in a position to pursue earlier. The data is therefore contextualised against a background of more dynamic academic communities, and of contemporary paradigms of identity as being spatial, fluid and contingent (Barnett and di Napoli 2008; Delanty 2008; Taylor 2008), rather than fixed around disciplinary territories.

Shifting patterns of academic activity are also reflected in employment data. According to the UK Higher Education Statistics Agency (HESA) (2010), only 52\% of academic staff, who in turn comprise $47 \%$ of the total higher education workforce in the UK, continue to undertake both teaching and research, traditionally seen as essential elements of being an academic. Furthermore, $17 \%$ of academic staff are described as grades 'other than' than professor, senior lecturer, lecturer etc, illustrating the difficulty of characterising emergent staff categories. Identities are forming in spaces that incorporate, for instance, professional, practitioner, and organisational, as well as disciplinary interests, and in extended locations such as external agencies and partners, outreach and offshore sites. Academically oriented project spaces may also be virtual or web-based, and residency multiple, overlapping, permanent or provisional.

Although the studies on which this paper draws were conducted in the UK, US and Australia, there is evidence that these contexts are also being experienced in Europe (Krucken, Blumen and Kloke 2009; Kehm, Merkator and Schneijderberg 2010; Nickel and Ziegele 2010; Zellweger Moser and Bachman 2010). It should also be noted, for the purposes of this paper, that the term 'administration', when used by respondents to refer to 'non-academic' work, has different meanings in US and UK/Australian contexts. In the UK and Australia, although originally derived from a civil service context, it now also tends to imply more routine or process oriented tasks. By contrast, in the United States, the term 'administration' is associated with institutional policy and governance, and the most senior institutional managers, including presidents, are referred to as 'administrators'. In this paper, the terms "functional" or "professional" are also used to describe activity that does not have academic components.

\section{Modifying binary perceptions}

Academic activity has traditionally been defined in relation to the broad categories of teaching, research, and in some higher education systems, third leg or service activity. The concepts of "Mode 1" and "Mode 2" (Gibbons, Limoges et al 1994) add a further dimension of practice-based research. Activity that does not fall precisely into these categories has tended to be described as 'non-academic', and this is reflected in employment statistics. Central to the academic/non-academic binary is a perceived split between collegial approaches, implying academic autonomy and freedom, underpinned by the contribution of higher education to the advancement of knowledge; and functional activity that is geared to institutional and socio-economic goals. This binary is reflected in an extensive literature (for instance Marginson and Considine 2000; 
Walker and Nixon 2004; Deem 1998, 2005; Fulton 2005); in the concept of the institutional "centre" and academic "periphery" (Clark 1998); and of "managed" and "managerial" professionals (Rhoades 1996; 1998).

More recently, there has been some recognition of "a new combined academic profession, which moves between expert roles, core activity and support services" (Aarrevaara and Holtta 2007: 208). External changes such as increased emphasis on Mode 2 and collaborative research, as well as more clearly defined institutional agendas, have led to a situation whereby "Academics have less well-defined and protected 'spaces of action' in which to determine and pursue their own academic agendas", "individuals are open earlier to extra-academic professional influences and identity possibilities..." and "academics, researchers and teachers are working in an environment of complex, differentiated social groups and influences, where structures and relationships are more fluid" (Henkel 2009: 84; 86; 88). Thus, Enders and de Weert describe an increasingly "T-shaped profession", involving both "depth of disciplinary knowledge and broader transdisciplinary knowledge and skills" in which "T-shaped people are equipped with competences and skills which are relevant for employment outside academia, but also for an increasing diversification of job tasks within the academic profession" (Enders and de Weert 2009: 262). Moreover, this is not necessarily happening by default, and "A mix of these components may be an attractive option for staff to have more flexibility in moving across different roles" (Enders and de Weert 2009: 265). Likewise, Clegg refers to universities as becoming "more complex and differentiated spaces... [in which] identities... are expanding and proliferating" (Clegg 2008: 330 and 343). Often such identities are derived from practice-based disciplines, which involve linkages "beyond the confines of the university" (Clegg 2008: 341), as well as increasing numbers of staff having fractional and short-term contracts, and associates from the public and private sectors who assist with teaching and research (Gordon and Whitchurch 2010).

Furthermore, there is a cadre of academically oriented staff with doctorates who may not have academic contracts, but who have acquired generic skills from formal research training programmes. As transferable skills become an integral component of both taught and research-based doctorates, in the UK and elsewhere (see for instance Research Councils UK 2001), it is likely that those possessing such skills will seek roles that are seen as stimulating as, but different from, mainstream academic roles. It is also significant in this connection that job advertisements for research managers in the UK began to specify doctorates from 2004 onwards (Shelley 2010: 49; see also Allen Collinson (2007, 2009) and Knight and Lightowler (2010) for a discussion of the developing roles and identities of research managers with both academic and functional responsibilities). There are also people who begin their careers in functional, as opposed to academic, roles, but who see acquiring a doctorate as a way of both gaining status and being able to extend their work:

“ 'School Managers with a PhD operate more autonomously and exert a more direct influence on outcomes where academic issues touch on business/financial matters"” (Berman and Pitman, 2010: 165).

These movements are borne out by the narratives of individuals with academic credentials and backgrounds who were employed in academically oriented, but nonmainstream academic activity. There was a sense from these narratives that a significant proportion of respondents could have gone either way, either into a mainstream 
academic, or into a more project oriented type of role. Moreover, some of the roles that they fulfilled, even if not categorised as academic in employment terms, specified academic skill sets. For instance, the job description of an institutional researcher in the US required:

"Knowledge of social science research design methods, including qualitative and quantitative research methods and descriptive and inferential statistics".

Other job descriptions specified both academic and project oriented experience, for instance that of a learning partnership manager in the UK which required "an experienced academic manager", not only with "the academic credibility to ensure that innovative and complex operations are delivered with high standards and quality", but also with "experience of generating external income and involvement in project management".

As has been the case for some time in, for instance, the applied sciences and professional disciplines, the studies provided further evidence that academic career pathways are becoming less linear, with the possibility of moving between higher education and other sectors. Thus:

"Individual choices might now be guided not so much by a clear hierarchy of esteem, established by dominant epistemic communities and centred upon achievements in scholarship and research, but by an evolving individual sense of value and aspirational priorities, as the process of self-definition and assessment of the availability of options takes place in a more fluid and less exclusive environment" (Henkel 2009: 91).

This was borne out by one respondent who noted a changing approach to careers by younger academics, especially those in practice fields:

"...professional faculty people do move in and out a lot. The younger ones are much more likely to go out and work for [a Research Council] for a couple of years, then come back, perhaps do some teaching in a school, come back, do some more academic work, go off and work for a government department, work on a project... there are fewer continuing positions... That also changes attitudes because they've got a broader view of the world as well and a context in which to put their university employment" (staff developer, Australia).

\section{Preferences, models and variables}

\section{Preferences}

When asked how they had found themselves outwith a mainstream academic role, respondents reported a range of reasons. Often it was a combination of circumstances involving career stages and lifestyles, for instance they had found their subject discipline too limiting or no longer interesting; they were no longer research active; they had discovered an aptitude for other types of activity, perhaps opportunistically; they preferred applied, Mode 2 forms of research; a project oriented role had offered a way into higher education, and/or offered more opportunities in relation to career development or funding; they had aspirations to go into higher education consultancy; they had an ideological commitment to a project such as widening participation; or it was a pragmatic decision such as needing to find a job in the same geographical area as a partner. Such preferences reflect findings elsewhere that some academic staff identify less with their discipline than with wider considerations "... shaped by the flux of 
events, discoveries, societal evolution, ethical positionings and so on... as the relation to the wider world is re-appraised" (Fanghanel 2012: 80-81).

At the more pragmatic end of the spectrum, one respondent had made a conscious decision to work in an academic environment, in the hope that it would lead to academic work, if not an academic appointment:

"I decided I wanted a job at ***. I wanted to be an academic, but going into academic administration had always been my fallback, because I knew universities and I didn't think I would be happy in the corporate world at all and I wanted to be in an academic environment. So I just started literally applying for any position on the campus that looked reasonable... I got the job [in institutional research] because I had the research skills they were looking for" (institutional researcher, US).

Another person with a strong academic record and career history had likewise focused on the institution, taking the view that:

"It's much better to be in a marginal position in a great university than it is to be in a full professor position in a marginal university" (community outreach manager, US).

For others, conscious that they could have gone either way, it was a question of the career stage they were at:

"If I were ten years younger, and had just done my doctorate, I would probably be looking at an academic career... Once people knew [I had a doctorate and published papers] a number of academics emailed me and started engaging with me... it has quite shifted my relationship with academics. I don't think it has changed their view of my role, but it has created a connection for us which certainly wasn't there before..." (student support manager, Australia).

Despite elements of pragmatism, however, the majority of respondents represented their positioning as a positive choice, as in the case of someone who had moved from an academic appointment to a policy-oriented one, so as to move to a role where they could apply their disciplinary knowledge as a statistician:

"I just got more enjoyment out of administrative work than I did out of teaching... doing theoretical research was not as exciting to me as doing applied research and seeing the direct benefits. That's one of the main reasons why [I shifted] - I wanted to see the direct benefit of what I'm doing" (institutional researcher, US).

\section{Models}

The data was analysed by developing descriptive codes for factual details arising from respondents' accounts, interpretive codes for possible latent meanings, and pattern codes for links or themes across the accounts (Miles and Huberman, 1994: 57). From the descriptive codes, a preliminary categorisation was constructed, describing each respondent's activity in terms of their relationship with institutional structures. Although this was not clear-cut in all cases, individuals were categorised according to the dominant features of this relationship. The analysis was an iterative process between the three sets of codes, and as this took place it became apparent that some institutions were more receptive to academically oriented project work than others, so that in some instances this had developed greater critical mass. In turn, some respondents were more embedded than others within formal structures. As a 
result of the process of analysis, three models of academically oriented project work emerged:

\section{The integrated model}

In the integrated model, academically oriented project roles were explicitly recognised and embedded in institutional structures, for instance in offices of institutional and policy research in the US. They typically involved people with a political science or sociological background, such as the following respondent:

"I was never $100 \%$ that I was going to stay along the faculty route... this is very much to me like a research-based academic job and what I have to do is a lot of data analysis, a lot of policy analysis... so I kind of see it as an openended funded research project on college access, choice and equity... [I see my identity] as a professional policy maker... even though I do have management responsibility for two people... [but] I can also see myself moving back to faculty. I want to keep writing and publishing... ours is an applied field which means that you can take a policy administration or industry job and still come back to faculty... because there are still things about faculty life I find I am missing... [such as] guiding dissertations, working with doctoral students, programme development" (institutional researcher, US).

The knowledge created by such an individual can be seen as applied, Mode 2 knowledge by the institution, of the institution. Another respondent referred to themselves as a "knowledge broker", offering technical expertise, analytical and interpretive capability, and making links between the different 'disciplinary' aspects of this:

"This job [institutional research] requires the mind of an anthropologist because, you know, in the job that I do, like a social scientist, you're probing for answers. And you're looking for patterns and you're studying people... you're looking at people's lives... looking at their performance in school, looking at the drop-out rates, you're following them around for four years, seeing what kind of classes they take... I feel like I'm an archaeologist digging around for information" (institutional researcher, US).

Furthermore, in the US there exists:

"a professional cadre of people who could have been faculty members, have the credentials, the training, and whose research is at that level, is a relatively long standing tradition... of an American university.... they can go as far as the work takes them... and go toe-to toe-with faculty" (educational outreach manager, US).

A critical mass of these types of roles across US institutions reinforces institutional and policy research as a specialist area of interest within the disciplinary field of higher education. Such disciplinary space is likely to be reinforced within individual institutions by the presence of interns from master's programmes wishing to learn about fields as diverse as policy analysis, recruitment patterns or equity issues. Students also become involved as subjects in research studies and as peer tutors to undergraduates, thereby making a direct contribution to teaching and research. Thus, an institutional researcher in the US described research into the student experience as "a joint academic and institutional project". 
There was also evidence in the US of the development and expansion of new forms of academically oriented space, for instance at the interface between the institution and its partner agencies in government and the community. The following respondent therefore saw a range of possibilities open to them:

"I think my love would be to... go back into academia... it wouldn't be very hard for me to make that transition... I'm teaching about higher ed and higher ed structures because I do it all the time on the job [for instance to interns and external delegations]... [Failing that] I would like progressively more responsible positions within the university, though probably still somewhere in this administrative interface between the university and the external world" (institutional researcher, US).

It was apparent that the integrated model appeared to provide the most stable environment for academically oriented project work. However, this was not universal, and depended to a significant degree on the approach of senior managers and executives. There were examples of individuals in integrated units who felt disempowered because they had not been kept in an information loop, or given feedback about the outcome of a decision to which they had contributed data and policy analysis, or because they felt that their contribution had been ignored. Others felt constrained by institutional bureaucracy or by being micro-managed by their line managers. In this type of arrangement, support and recognition from the senior management team, or a senior figure, was critical.

\section{The semi-autonomous model}

In all three countries there were examples of people who worked on academically oriented projects that were located in semi-autonomous units, which were fully or partly self-funding, such as spin out, enterprise or learning partnerships:

“... we're a hybrid; so business and professional development short courses... traditional continuing professional development sit within the section as well. It has to generate income. The collaborative partners bring in income, but learning and teaching is much more of a service provider in some ways, although it has got a number of funded projects" (learning partnerships manager, UK).

Such locations appeared to be the most rewarding for the individuals concerned, in that they had a degree of autonomy and were likely to have direct responsibility for the viability, financial or otherwise, of their projects. Although this responsibility could lead to significant challenges and tensions, their positioning seemed to offer individuals the sense of a direct stake in their project, and greater opportunity to fulfil the potential of their roles. They were likely to experience a full range of responsibilities, in which they could be thrown back on their own resources, the highs and lows of which were exemplified by a learning support manager in the US:

\section{Learning support manager, US}

This individual was studying for a doctorate and worked in a unit promoting access to the university for non-traditional and disadvantaged students, in which "you can get tutoring, you can get counselling, you can do career planning..." They saw themselves as having academic, professional and management interests. In an earlier role they had had teaching responsibilities, and had moved into their current position 
by chance: "I enjoyed connecting one to one with students, and found that I was effective at it, and I didn't even know it was really a career, so I [became] an academic adviser helping students to select courses and understand academic policies". Nevertheless, "staying current" in the field was of paramount importance: "Networking is invaluable, and when I go to conferences I feel energised, I feel recharged... I'll present a paper here and there..." However, there were stresses in covering all bases: "I feel like I have a good deal of autonomy in my work. It's pretty much up to me how I do things... but I'm managing a service in a lot of ways, so I think depending on what role I'm in I feel more like one or the other... I often feel the tug between, you know, the responsibility to the students and to the campus, and then the responsibility of kind of, you know, paying the bills, because we're a selfsupporting unit... I have to make decisions because I need to balance the budget." There were also budgetary constraints, for instance, in employing a researcher to develop understandings about the learning modes of less advantaged students, as well as an awareness that "we can put ourselves out of business very easily". A key challenge, therefore, was in relating the more academic aspects of the role to the dayto-day realities of management responsibilities: "we talk about things in an ideal world in the classroom in theory. But then when you actually come to work and try to do it, it doesn't always happen... being such a human, service-oriented type of programme, having that financial responsibility is tough." Nevertheless: "it's a great place to be, I love it, I want to spend more time in it, and have ideas about I should do this research or publish that paper... I hope that in future I will be able to do more research and publishing..."

Although such positioning in a semi-autonomous unit was less protected, involved more risk, and could mean direct involvement in "highly charged political environment" (partnership manager, US), it provided the stimulus that some individuals were looking for outside the mainstream:

"I actually enjoy the politics, it's part of what makes life interesting... the power struggles and the battles that go on and the fighting over the contested areas, I find that quite stimulating..." (learning partnerships manager, UK).

Such individuals were also likely to represent their institutions in developing key relationships with external partners and in building external networks, which was a motivating factor for some:

“.... we're evangelists for learning [and] I think that's wonderful... if we can widen the range of the organisations we can help, which is why I came to work [here], to try and put something back" (learning technology manager, $\mathrm{UK})$.

\section{The independent model}

There were also examples of individuals who worked more independently, often by choice, within traditional institutional structures in which there was no critical mass of space related to their specific project. Thus one individual, although having an academic background and working on institutional policy, occupied what was categorised in institutional terms as an administrative or service role. They were therefore obliged to work around their formal positioning, adopting appropriate forms of language so to counter perceptions that were undertaking either a service or a management function: 


\section{Policy and planning manager (UK)}

This person, who had a doctorate, had been an academic manager in the college sector where they had co-ordinated a degree programme: "leading the expansion of the degree programme across the whole college... moving away from [my subject discipline]... I gained a lot of experience of academic management... I'd been doing lots of curriculum framework projects... I had a small project grant, that kind of thing". On moving to a higher education institution they found that: "I ended up in university administration, with no concept of what it was, no particular career aspiration to be a university administrator, and when I got here I realised... some of the boundaries placed around 'administration'. That's certainly not the way I'd ever operated, or expected to operate... and something you have to work through". On a day-to-day basis, they saw themselves as "as working in partnership" with academic colleagues, notwithstanding their positioning in 'the administration', "especially once... academics begin to appreciate the sort of things that my involvement can bring". Their academic background enabled them to work with departments in developing academic initiatives and applying for research funding: "This paper I'm writing at the moment... I'm leading the bid... because I've got the experience and... the understanding of the institutional context that's needed to put something like that together". By building both academic and institutional knowledge, therefore, they were in a position to add value to the initiative, but were conscious of working within given structures and of suppressing both their 'academic' and 'non-academic' identities in order to achieve outcomes. At times it was necessary to engage in a type of 'doublespeak', therefore, in order to develop and maintain key relationships with both academic colleagues and senior managers: "It's about adapting the way we actually work to fit in with the organisational culture... If I were working in a different organisation, I would see myself as a manager. I don't think that that's a particularly valid concept here... You can't make anybody do anything unless they think it's a good idea. There is a lot of hostility to the word management, of management of academic matters by people who are not actually academics, or if they are academics, not academically involved in that particular area... so I think it's safer to call it administration." This person, therefore, created, and to an extent negotiated, their own space on the basis of the unique contribution that they were able to make outwith formal organisational categories.

By contrast, the academic component of another UK respondent's role was accommodated more visibly in a 50:50 academic/non-academic contract, which acknowledged their contribution to the development of teaching and learning programmes for widening participation students:

"I don't really see myself as an academic in the sense that I'm not like a normal academic in higher education... because I come in from a completely different route... but even though I love being partly academic, I also enjoy being part of a management team, knowing... I can influence [things]... at the grass roots level" (widening participation manager, UK)

This person felt that formal recognition of their dual contribution in a split appointment was vital to making a success of their institution's widening participation mission, to which they were strongly committed, with an ambition to progress in the field at a national level.

Other individuals who worked relatively independently occupied what might be described as 'academic consultant' roles: 


\section{The 'academic consultant' (Australia)}

This person had a background in the commercial world and ran their own business at the same time as working in the university. They were employed for their contribution to specific projects, and at any one time were likely to have multiple, fractional contracts. As well as project management roles they also taught on degree programmes. They had a full range of teaching responsibilities including lecturing, tutoring, marking, and developing programme materials and online provision. Organisationally they worked between an academic department, an educational technology unit and a skills unit. They described themselves as having acquired an "academic headset" which enabled them to move between environments: "I find that I can get through to academic staff a lot easier and a lot quicker because they accept me as one of them. I don't have [academicadministrator] tensions because I've taught on the courses... if I was living in a school or a division there'd be all this ongoing [political] stuff. I'm actually committed to the project and to getting the work done for the university, and that's where my heart is". However, in order to become an academic they had to "go casual", which meant that "you teach more remotely, and you just have contact... with your programme and particularly with the academic that's employing you". Their teaching contracts had arisen through individual contacts and networks: "I'm a good networker, so I know the people in lots of areas across the university, which is good because it means I can get work, but it also means that the word spreads that I do the job well through this network". The downside of being "casual" was that they were not necessarily "plugged in' to all communication channels such as all-staff emails. As a result: "I've never been on a career path as such, and I don't consider myself on a career path [either academic or professional]". They saw themselves rather as "moving along a path, achieving work for the university that benefits academics and students... and showing both academics and administrators that they can think kindly of each other and work together". They did not therefore fit into any employment category, and their ideal would have been to have an ongoing role with "modules in your job description that you could fill with [different] activities". They regretted the fact that "there are no positions that allow you to teach and project manage in one role... In the business world there is a great deal more freedom in creating positions that suit the needs of the organisation. We don't have that in the university sector and I think that's a real shame". This person was involved in bespoke arrangements and relationships, and created links between the different aspects of their work, for instance by using their project work as case material in teaching. Although they were not working within the parameters of a precise job description or clear organisational structures, their contribution was nevertheless geared to achieving optimal academic outcomes.

It may be that such split and fractional types of appointment will become more widespread in future in response to the lifestyle preferences of individuals, as well as in response to diversifying institution missions and resource pressures.

The spread of respondents across each model of academically oriented project activity is shown in Table 2:

[insert Table 2 here]

In theoretical terms, the relationship between respondents and their institutions can be seen through the lens of structure and agency as articulated by, for instance, Giddens (1991) and Archer (2000). Individuals working within the integrated model might be 
seen as both "animating" (acting out) and "personifying" (investing in) (Archer 2000) the role of translator between different internal constituencies, and between the institution and external agencies. Thus, their roles are defined to a significant extent by existing structures, which can be both enabling (for instance by allowing discretion in the presentation of academic initiatives in ways that are appropriate to specific external funders) and constraining (for instance by exclusion from strategic decision and policy making). Those in the semi-autonomous model are more likely to be able to exercise agency in developing their project, and also in influencing existing institutional structures and processes, especially if they are able to use the leverage that comes from a successful project. Those represented by the independent model exercise agency in working around existing structures, rather than their activity being determined by, for instance, the formal parameters of a job description. They are also likely to operate under the assumption that they are not in a position to influence or change such structures.

With a caveat about conclusions that can be drawn from a sample of twenty-five respondents in nine institutions, the integrated model was more evident in the US, where academically oriented activity was of longer standing, with the establishment of offices dedicated to specific project areas, notably institutional research. The semiautonomous model appeared to be more evident in the UK, which might be accounted for by an expansion of self-funding units alongside an increased market orientation in the UK system. In Australia the spread of individuals across the three models was more evenly balanced. The semi-autonomous and independent models appeared to generate more criticality of existing structures, although those individuals working within the semi-autonomous model had a greater sense of being able to influence both specific projects and mainstream agendas. In the independent model, energy was likely to be expended on working round formal structures, which could reduce the time available to progress individual projects. In the integrated model, projects were more likely to be prescribed by institutional policy, and respondents might or might not feel that they had a voice in decision-making.

\section{Variables}

Those who settled in academically oriented project roles were likely to be comfortable with a certain amount of ambiguity and tension, finding that this enabled them to exercise a degree of autonomy in setting their own agendas:

"I've always worked at interfaces... I've never been mainstream and I've always enjoyed being at the interface, and although I will use it, and occasionally say 'well of course we're just the marginalized'; but no, that's where I like to be. I like to be where it doesn't matter if you bend the rules or do things differently or... no one is quite taking any notice..." (learning partnerships manager, UK)

Learning to accommodate and work with dissonance became a modus operandi, with a reliance on personal agency as opposed to organisational structures or information flows:

“... I've had to create my own role, find my own ways into systems and force my way into meetings, rather than wait for someone to ask me to contribute" (learning technology manager, UK) 
This was particularly the case in the UK and Australia, perhaps reflecting the fact that such roles were less established and recognised than in the US. There was a sense that individuals could not necessarily draw on positional authority or expertise, and had to build their own credibility outside organisational safety nets:

"There's no authority that you come with" (policy and planning manager, UK) "It's what you are, not what you represent" (learning partnerships manager, UK)

Furthermore, being able to take the part of academic colleagues, for instance, understanding academic work rhythms, and the possible disjunction with time and budgetary parameters, was an important element in progressing their projects, as well as in building confidence and trust. As one respondent put it, academic colleagues tended to take the view that "If you solve a problem for us, we'll come back and work with you again" (learning and teaching manager, UK).

Thus, while 'hard' factors such as institutional structures were significant in defining the type of space available for those in academically oriented project roles, it was also apparent that 'soft' factors, such as the attitudes of and relationships with colleagues, were likely to have a stronger influence on the roles of individuals. Therefore those in integrated space such as an office of institutional research might or might not have a voice in institutional decision-making. In addition to the agency adopted by the individual, and the type of organisational space that they found themselves working in, the following variables were also apparent across all three countries:

- The flexibility of organisational "rules and resources" (Giddens 1991).

- The influence of senior manager(s) in encouraging an innovative approach to the development of a specific project area.

- The scope that existed for individuals to develop their project in ways in which they judged to be appropriate.

- The nature of the project and the stage of its development.

- The influence of team members, external partners and colleagues.

However, there is undoubtedly scope, particularly in straitened economic times, for perceptions that academically oriented project work reduces rather than expands the space for disciplinary activity, and consumes resources that might otherwise be used for the latter. Even where the potential for joint working is acknowledged, some commentators continue to see this as involving a division of labour between academic and professional staff, with a loss of control on the part of academic staff, rather than as a mutual and collaborative endeavour:

- 'a 'marriage' between professionalism and managerialism [involves] academics losing some control over the goals and social purposes of their work..." (Kogan and Teichler, 2007: 11).

- "the use of instructional information technology 'unbundles' traditional faculty instructional practices, breaking down the teaching function into multiple, discrete parts, reducing professors to content experts" (Rhoades, 2007: 6)

Others, for instance, Macfarlane $(2007 ; 2011)$, see this as reducing the role of mainstream academic staff as "academic citizens", so that "more often than not undertaking a hybrid role was seen as a struggle and sometimes even dysfunctional..." (Macfarlane 2011: 71). 
An alternative view would be that academically oriented activity releases academic staff to focus on disciplinary and research activity that interests them, especially in periods of retrenchment when academic staff are obliged to account more closely for their time in relation to mainstream teaching and research, and have less time for pastoral and support activities:

"the push within our university is very much to try and relieve the administrative burden off academic staff; that needs to happen and some academics are reluctant to give it away" (student services manager, Australia).

There are also signs that such contributions are sought and appreciated:

"I think there are increasingly role models showing that you can actually have a voice. And it's not about taking over academic decision-making. It's about adding value rather than negating the contribution of academic staff... [we] as a group have been able to change some policies in areas where we've in the past been told 'get lost'" (faculty manager, Australia).

Another respondent had built up expertise in advising academic staff about the authoring of funding bids, including drafting sections of such bids so as to meet the criteria of funding bodies, with significant success rates. Internal consultant roles could also be seen as an example of a casualisation of (particularly) academic roles, although they might suit individuals who prefer building a portfolio of experience in different spheres, so as to leave options open for the future. Such individuals may be of increasing value to institutions in bringing a range of experience to bear, particularly those from practice disciplines and/or with project expertise.

\section{Implications of academically oriented project roles}

The increasing range of identities with academic components, some of which might not be fully recognised in formal organisational frameworks, widens the scope of career pathways for academic staff. For instance, they have the possibility of:

- making a career of academically oriented project work

- moving in and out of project work but staying in higher education

- reverting to mainstream academiamaking a career in another sector eg policy/funding agencies, business/industry, NGOs or third sector.It also raises questions about how the contributions of individuals might be optimised, both in terms of their own career futures and of contemporary institutional missions. Issues arise around, for instance the weightings that might be accorded to applied research and practice, publication records, and contributions to external networks and partnerships vis-à-vis rewards, incentives, and career advancement. Individual cases may need to be judged on a one-off basis, with no institutional guidelines or direct comparators. This is likely to be particularly acute when there are mixed teams of staff within a single project or unit. Thus:

"None of the work we do... makes any sense outside the context of a faculty... or of students in departments, whether it's learning support, or counselling, or an administrative process... yet there is a difficult leadership role in integrating and managing the staff in the unit who are a combined group of academic and administrative staff undertaking similar work with different working conditions and entitlements" (learning support manager, Australia).

Difficulties were also mentioned in relation to conditions of service, intellectual property, and entitlement to support for conferences. In a US institution there was 
also an issue about institutional researchers being funded to go to conferences and give papers, partly in order to gain intelligence for the institution about issues such as recruitment, when funding might not be available for mainstream academic staff wanting to go to conferences in their discipline. Ongoing negotiation is likely to be required about such issues, alongside recognition of more flexible career pathways with opportunities for crossover, exit and re-entry, along the lines of, for instance, Strike's "career climbing frame" (Strike 2010).

Although respondents in the study generally took the view that their projects represented an enhancement of their roles and identities, there was the possibility that, as one respondent with a scientific background put it, academic colleagues would consider you a "failed scientist":

"that's still something that a lot of people who have made a move out of research have to battle with... often I think by people who wish they had done so... I prefer to be more in a leadership role for something that's project related, that's innovative..." (research manager, Australia).

Furthermore, although respondents themselves continued to see themselves as academics, there could also be adverse reactions from academic colleagues to the value of project oriented work, even if it involved research (which was likely to have a practical, Mode 2 bias):

“...you're not regarded as a real academic, and yet I've probably done more as an academic than many academics have done this year... The interesting thing is, the research I'm doing on university corporate partnerships has given me an area of expertise to do with 'business' that [is regarded] as dirty, and not as real academic stuff" (partnerships manager, Australia).

This was echoed by a widening participation manager in the UK, who described negative attitudes to their unit's research as being seen as "trade or dirty work".

There could also be tensions around the fact that a doctorate does not automatically confer the skills required to undertake a specific role. Thus:

"I have a couple of PhDs on my staff. They were trained to do research as a $\mathrm{PhD}$, which you can't do... you can't give a dissertation to a provost or a chancellor. They want the one pager. So you have this disconnect between how you present the data and the style in which to present it" (institutional researcher, US).

Learning how to present material in an appropriate format, including where necessary "sound bites" (for instance for politicians), was therefore a significant dimension to academically oriented project work. Another respondent saw the need to develop specific technical skills:

"there's this disjunction coming out of an academic research background where I have the conceptual and the writing skills, probably at a much higher level of mastery than people in the field I'm in; but what they have that I don't have are really highly developed technical skills, and I work with that. I work between the cracks... I recently decided that in terms of professional development, what I really need to do is to upgrade my technical skills" (institutional researcher, US).

At a practical level, the location of academically oriented projects could also lead to inappropriate line management arrangements whereby, for instance, someone with significant academic content to their role was managed by someone with mainstream 
functional responsibilities. Perhaps for this kind of reason, there were respondents who considered that having low visibility and/or ambiguous organisational positioning could be an advantage, allowing more scope for autonomous activity. As one Australian respondent reflected, "The model where we almost disappear is not a bad one...", because it allowed the activities of learning support staff to "merge" with those of academic colleagues, and the two groups to work seamlessly together. This suggests that, at times, it was necessary to use a degree of dissemblance in order to make things work, particularly in Australia, where there appeared to be a stronger sense of the academic/non-academic binary, and less recognition of academically oriented project identities per se.

\section{Conclusion}

The studies suggest that the terms 'academic' and 'non-academic' no longer represent a clear binary division in higher education, and that there is a spectrum of activity that involves staff with academic credentials and experience, even though they may be employed on non-academic or split contracts. Academic identities, therefore, are both expanding and becoming more heterogeneous. Moreover, being involved in broadly based, academically oriented institutional projects appears to be a positive choice for some individuals who could have gone in either an academic, or a more projectoriented direction. Three models of academically oriented activity were identified as being integrated within institutional structures and agendas, semi-autonomous as a result of being partly or fully self-funding, and independent, whereby respondents tended to work around existing structures on their own initiative. It was suggested that organisational arrangements involving semi-autonomous units, dedicated to a broad project area, provided the optimal conditions for academically oriented identities to flourish, although the approaches of the senior management team, as well as the agency of individuals, were also contributory factors.

Furthermore, the contribution of people with academic credentials, but also specialist skills in areas such as the design of online programmes and bids for funding, are likely to continue to be required to support the academic endeavour of both individuals and institutions in contemporary environments. Notwithstanding national and institutional variables, the development of academically oriented project work appears to both co-exist with and extend mainstream academic activity. Not only are there more spaces for those with academic credentials and experience to inhabit in the contemporary university, but also more possibilities for them to develop nonmainstream careers in the longer term. This suggests that "constructive interaction" (Kolsaker 2008: 523) between academic and project oriented activity is likely to be ongoing. Furthermore, individuals in these roles are likely to add to the "plurality of voices" and a "re-imagining of academic identities" in higher education (Fanghanel 2012: 81). However, the recognition accorded to these roles and identities varies according to national and institutional cultures and traditions. Both institutions and individuals, therefore, may wish to think about how they articulate the added value that they bring, to themselves and to colleagues.

\section{References}


Aarrevaara, T. and S. Holtta (2007). Finland: Massification, Steering-By-Results and New Divisons of Labour. The Changing Conditions for Academic Work and Careers in Select Countries. Kassel, INCHER-Kassel: 195-208.

Allen-Collinson, J. (2007). "'Get yourself some nice, neat, matching box files!' Research administrators and occupational identity work." Studies in Higher Education 32(3): 295-309.

Allen-Collinson, J. (2009). "Negative 'marking'? University research administrators and contestation of moral exclusion." Studies in Higher Education 34(8): 941-954.

Archer, M. (2000). Being Human: The Problem of Agency. Cambridge, Cambridge University Press.

Barnett, R. and R. di Napoli (2008). Changing Identities in Higher Education: Voicing Perspectives. Abingdon, Routledge.

Becher, T. and P. Trowler (2001). Academic Tribes and Territories: Intellectual Enquiry and the Culture of Disciplines. Buckingham, SRHE/Open University Press.

Berman, J. E. and T. Pitman (2010). "Occupying a 'third space': research trained professional staff in Australian universities." Higher Education 60(2): 157-169.

Clark, B. (1998). Creating Entrepreneurial Universities: Organisational Pathways of Transformation. Paris, International Association of Universities Press and Elsevier Science.

Clegg, S. (2008). "Academic identities under threat?" British Educational Research Journal 34(3): 329-345.

Deem, R. (1998). "'New managerialism' and higher education: The management of performance and cultures in universities in the United Kingdom." International Studies in Higher Education 8(1): 47-70.

Deem, R. (2005). 'New Managerialism' and the Management of UK Universities. ESRC End of Award Report.

Deem, R., S. Hillyard and M. Reed (2007). Knowledge, Higher Education, and the New Managerialism: The Changing Management of UK Universities. Oxford, Oxford University Press.

Delanty, G. (2008). Academic Identities and Institutional Change. Changing Identities in Higher Education: Voicing Perspectives. Eds. R. Barnett and R. di Napoli. Abingdon, Routledge.

Dowd, K. O. and D. M. Kaplan (2005). "The career life of academics: Boundaried or boundaryless?" Human Relations 58(6): 699-721. 
El-Khawas, E. (2008). Emerging Academic Identities: A New Research and Policy Agenda. From Governance to Identity: A Festschrift for Mary Henkel. Eds. A. Amaral, I. Bleiklie and C. Musselin. Dordrecht, Springer.

Enders, J. and de Weert, E. (2009). The Changing Face of Academic Life: Analytical and Comparative Perspectives. Basingstoke, Palgrave Macmillan.

Fanghanel, J. (2012). Being an Academic. Abingdon, Routledge.

Fulton, O. (2003). Managerialism in UK Universities: Unstable Hybridity and the Complications of Implementation. The Higher Education Managerial Revolution? Eds. A. Amaral, V. L. Meek and I. M. Larsen. Dordrecht, Netherlands, Kluwer Academic Publishers.

Gibbons, M., C. Limoges, H. Nowotny, S. Schwartzman, P. Scott and M. Trow. (1994). The New Production of Knowledge, the Dynamics of Science and Research in Contemporary Societies. London, Sage Publications.

Giddens, A. (1991). Modernity and Self-Identity: Self and Society in the Late Modern Age. Cambridge, Polity Press.

Gordon, G. and C. Whitchurch (Eds.) (2010). Academic and Professional Identities in Higher Education: The Challenges of a Diversifying Workforce. International Studies in Higher Education. New York, Routledge.

Henkel, M. (2000). Academic Identities and Policy Change in Higher Education. London, Jessica Kingsley.

Henkel, M. (2009). Policy Change and the Challenge to Academic Identities. The Changing Face of Academic Life: Analytical and Comparative Perspectives. Eds. J. Enders and E. de Weert. Basingstoke, Palgrave Macmillan: 78-95.

Higher Education Statistics Agency (HESA) (2010). Resources of Higher Education Institutions 2008/09. Cheltenham, Higher Education Statistics Agency.

Kehm, B., N. Merkator, and C. Schneijderberg. (2010). "Higher Education Professionals - an Unknown Species." Zeitschrift fur Hochschulentwicklung 5(4).

http://www.zfhe.at/zfhe/xowiki/artikelview?ausgabe=de:282543.

Knight, C. and C. Lightowler (2010). "Reflections of 'knowledge exchange professionals' in the social sciences: emerging opportunities and challenges for university-based knowledge brokers." Evidence and Policy 6(4): 543-56.

Kogan, M. and M. Teichler (2007). Key Challenges to the Academic Profession. Paris and Kassel, International Centre for Higher Education Research Kassel.

Kolsaker, A. (2008). "Academic professionalism in the managerialist era: a study of English universities." Studies in Higher Education 33(5): 513-525. 
Krucken, G., Blumel, A. and Kloke, K. (2009). Towards Organisational Actorhood of Universities: Occupational and Organizational Change within German University Administrations. FOV Discussion papers 48. www.foev-speyer.de.

Macfarlane, B. (2007). The Academic Citizen: The Virtue of Service in Academic Life. New York, Routledge.

Macfarlane, B. (2011). "Professors as intellectual leaders: formation, identity and role." Studies in Higher Education 36(1): 57-73.

Marginson, S. and M. Considine (2000). The Enterprise University: Power, Governance and Reinvention in Australia. Cambridge, Cambridge University Press.

Nickel, S. and F. Ziegele (2010). Karriereforderung im wissenschaftsmanagement nationale und internationale modelle. Gutersloh, CHE/CHEPS/ESMU.

Research Councils UK (2001). Joint statement of skills training requirements of research postgraduates: www.rcuk.ac.uk/rescareer/rcdu/training.htm.

Rhoades, G. (1996). "Reorganising the faculty workforce for flexibility: Part-time professional labour." Journal of Higher Education 67(6): 624-659.

Rhoades, G. (1998). Managed Professionals: Unionized Faculty and Restructuring Academic Labor. New York, State University of New York.

Rhoades, G. (2007). "Technology-enhanced Courses and a Mode III Organization of Instructional Work". Tertiary Education and Management 13(1): 1-17.

Shelley, L. (2010). "Research managers uncovered - Changing roles and 'shifting arenas' in the academy." Higher Education Quarterly 64(1): 41-64.

Strike, T. (2010). Evolving English academic career pathways. Academic and Professional Identities in Higher Education: The Challenges of a Diversifying Workforce. Eds. G. Gordon and C. Whitchurch. New York, Routledge.

Stromquist, N. P., Gil-Anton, M., Colatrella, C., Mabokela, R. O., Smolentseva, A. \& Balbachevsky, E. (2007). The Contemporary Professoriate: Towards a Diversified or Segmented Profession? Higher Education Quarterly 61(2), 114-135.

Taylor, P. (2008). Being an Academic Today. Changing Identities in Higher Education: Voicing Perspectives. Eds. R. Barnett and R. di Napoli. Abingdon, Routledge.

Walker, M. and Nixon, J. (2004). Under New Management? Reclaiming Universities from a Runaway World. Buckingham, SRHE/Open University Press

Whitchurch, C. (2008). "Shifting Identities and Blurring Boundaries: The Emergence of Third Space Professionals in UK Higher Education." Higher Education Quarterly (62(4): 377-396. 
Whitchurch, C. (2009). "The Rise of the Blended Professional in Higher Education: A Comparison between the UK, Australia and the United States." Higher Education 58(3): 407-418.

Whitchurch, C. and P. Law (2010). Optimising the Potential of Third Space Professionals in UK Higher Education. London, Leadership Foundation for Higher Education (www.lfhe.ac.uk/research/smallprojects/sdprojectreports.html).

Zellweger Moser, F. and G. Bachmann (2010). "Between administration and academia - new roles in higher education." Zeitschrift fur Hochschulentwicklung 5(4): 1-8. http://www.zfhe.at/zfhe/xowiki/artikelview?ausgabe=de:282543. 